\title{
DECEMBER 1973
}

THIRTEENTH YEAR - No. 153

\section{international review of the red cross}

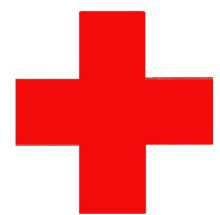

INTER ARMA CARITAS

\section{GENEVA}

INTERNATIONAL COMMITTEE OF THE RED CROSS FOUNDED IN 1863 


\section{INTERNATIONAL COMMITTEE OF THE RED CROSS}

Mr. ERIC MARTIN, Doctor of Medicine, Honorary Professor of the University of Geneva, President (member since 1973)

Mr. JEAN PICTET, Doctor of Laws, Chairman of the Legal Commission, Vice-President (1967)

Mr. HARALD HUBER, Doctor of Laws, Federal Court Judge, Vice-President (1969)

Mr. HANS BACHMANN, Doctor of Laws, Director of Finance of Winterthur (1958)

Mr. DIETRICH SCHINDLER, Doctor of Laws, Professor at the University of Zurich (1961)

Miss MARJORIE DUVILLARD, Nurse, former director of the Bon Secours Nursing School, Geneva (1961)

Mr. MAX PETITPIERRE, Doctor of Laws, former Swiss Federal Councillor (1961)

Mr. ADOLPHE GRAEDEL, former member of the Swiss National Council, former Secretary-General of the International Metal Workers Federation (1965)

Mrs. DENISE BINDSCHEDLER-ROBERT, Doctor of Laws, Professor at the Graduate Institute of International Studies, Geneva (1967)

Mr. MARCEL A. NAVILLE, Master of Arts, ICRC President from 1969 to 1973 (1967)

Mr. JACQUES F. DE ROUGEMONT, Doctor of Medicine (1967)

Mr. ROGER GALLOPIN, Doctor of Laws, former ICRC Director-General (1967)

Mr. WALDEMAR JUCKER, Doctor of Laws, Secretary, Union syndicale suisse (1967)

Mr. VICTOR H. UMBRICHT, Doctor of Laws, Managing Director (1970)

Mr. PIERRE MICHELI, Bachelor of Laws, former Ambassador (1971)

Mr. PIERRE BOISSIER, Bachelor of Laws, Director of Henry Dunant Institute, Geneva (1973)

Mr. GILBERT ETIENNE, Doctor of Laws, Professor at the Graduate Institute of International Studies, Geneva (1973)

Mr. ULRICH MIDDENDORP, Doctor of Medicine, head of surgical department of the Cantonal Hospital, Winterthur (1973)

Miss MARION ROTHENBACH, Master of Social Work (University of Michigan), Reader at the Ecole des Sciences sociales et politiques of the University of Lausanne (1973)

Honorary members : Mr. JACQUES CHENEVIERE, Honorary Vice-President ; Miss LUCIE ODIER, Honorary Vice-President ; Messrs. GUILLAUME BORDIER, CARL J. BURCKHARDT, PAUL CARRY, Mrs. MARGUERITE GAUTIER-VAN BERCHEM, Messrs. SAMUEL A. GONARD, EDOUARD de HALLER, RODOLFO OLGIATI, PAUL RUEGGER, FREDERIC SIORDET, ALFREDO VANNOTTI, ADOLF VISCHER.

\section{EXECUTIVE BOARD}

Mr. ROGER GALLOPIN, President

Mr. VICTOR H. UMBRICHT, Vice-President

Mrs. DENISE BINDSCHEDLER-ROBERT

Mr. GILBERT ETIENNE

Dr. ULRICH MIDDENDORP

Mr. GOTTFRIED DE SMIT

Mr. PIERRE MICHELI, Deputy member 


\section{CONTENTS}

INTERNATIONAL COMMITTEE OF THE RED CROSS

IN THE RED CROSS WORLD

\section{MISCELLANEOUS}

\section{INTERNATIONAL REVIEW OF THE RED CROSS}

DECEMBER 1973 - No. 153

XXIInd Internatlonal Conference of the Red Cross Opening Session Speeches..............

The International Committee's Action in the Middle East ....................... 640

External Activities :

Chile - Mission in West Africa - Rhodesia Mozambique - Asian sub-continent. . . . . . . . 649

In Geneva :

A new ICRC film ................... 652

ICRC publications in Arabic ............ 652

Teheran Meetings of International Red Cross ... 654

International Red Cross Assistance in Indo-China 657

Promotion of Red Cross Image .......... 658

World Red Cross Day - "Give Blood... Save Life " 661

World Congress of Peace Forces......... 662

National Sovereignty and Human Rights...... 663

Nurses and the Geneva Conventions........ 665

Contents $1973 \ldots \ldots \ldots \ldots \ldots \ldots \ldots \ldots \ldots \ldots, 669$ 


\section{FRENCH EDITION}

OF THE REVIEW

\section{SUPLEMENTS TO THE REVIEW}

\section{SPANISH}

GERMAN

\section{INTERNATIONAL \\ REVIEW OF THE RED CROSS}

The French edition of this Review is issued every month under the title of Revue Internationale de la Croix-Rouge. It is, in principle, identical with the English edition and may be obtained under the same conditions.

XXII Conferencia Internacional de la Cruz Roja - Una publicación del Comité Internacional de la Cruz Roja Día Mundial de la Cruz Roja: " Da tu sangre... Salva una vida " - Indice - Vol. XXV (1973).

XXII. Internationale Rotkreuzkonferenz - Ein neuer Film des IKRK - Kolloquium über den seelsorgerischen und den geistigen Beistand in bewaffneten Konflikten und innerstaatlichen Wirren - Ein Kindergesundheitszentrum Die Wahl fiel auf das Rote Kreuz... ! - Inhaltsverzeichnis Band XXIV (1973).

The International Review is published each month by the International Committee of the Red Cross

7, avenue de la Paix, 1211 Geneva 1, Switzerland Postal Cheque No. 121767

Annual subscription: Sw. Fr. 30.- (\$8)

Single copies Sw. Fr. 3.- $(\$ 0.80)$

Editor : J.-G. LOSSIER

The International Committee of the Red Cross assumes responsibility only for material over its own signature. 